\title{
The Effect of the Ruthenium Crystallite Size on the Activity of Ru/Carbon Systems in CO Methanation
}

\author{
Elżbieta Truszkiewicz ${ }^{1} \cdot$ Kacper Zegadło $^{1} \cdot$ Damian Wojda $^{1} \cdot$ Bogusław Mierzwa $^{2} \cdot$ \\ Leszek Kępiński ${ }^{3}$
}

Published online: 31 May 2017

(c) The Author(s) 2017. This article is an open access publication

\begin{abstract}
The influence of the ruthenium crystallite size on the catalytic activity of Ru/graphitized carbon systems in carbon monoxide methanation was evaluated. Four graphitized carbon materials differing in their surface area were used as supports for $\mathrm{Ru}$. The average size of $\mathrm{Ru}$ crystallites in $\mathrm{Ru} / \mathrm{C}$ materials was estimated by $\mathrm{X}$-ray powder diffraction, transmission electron microscopy and CO chemisorption. Dispersion of the active phase clearly depends on the carbon texture. The activity tests conducted in $\mathrm{H}_{2}$-rich streams with very low $\mathrm{CO}$ concentrations ( $0.5 \mathrm{vol} \% \mathrm{CO}$ ) have shown that the activity of Ru/carbon catalysts changes with the ruthenium particles size (d). The highest activities were obtained for ruthenium particles in the range $4-8 \mathrm{~nm}$ in size.
\end{abstract}

Keywords CO methanation - Ruthenium catalysts . Graphitized carbon support $\cdot$ Ru crystallite sizes

\section{Introduction}

The methanation of $\mathrm{CO}$ is widely used in industrial plants for the preparation of synthesis gas for ammonia synthesis $[1,2]$. The CO hydrogenation has also attracted increasing

Elżbieta Truszkiewicz

etruszkiewicz@ch.pw.edu.pl

1 Faculty of Chemistry, Warsaw University of Technology, Noakowskiego 3, 00-664 Warsaw, Poland

2 Institute of Physical Chemistry of the Polish Academy of Sciences, Kasprzaka 44/52, 01-224 Warsaw, Poland

3 Institute of Low Temperature and Structure Research of the Polish Academy of Sciences, Okólna 2,

50-950 Wrocław, Poland interest recently because of its potential as a simple technique for $\mathrm{CO}$ removal from $\mathrm{H}_{2}$-rich feed gases for fuel cells [1, 3-7]. Due to the poor reserves of natural gas in some regions of the world, conversion of syngas from coal or biomass to synthetic natural gas ( $\mathrm{SNG}$ ) via the methanation reaction is also attracting great attention [8-11]. That is the reason why many groups are still working to obtain highly active and selective catalysts for that reaction.

Supported Ni-based catalysts have been applied commercially on methanation due to their high activity, selectivity to $\mathrm{CH}_{4}$ and low costs $[1,8,11]$. However, hydrogenation of $\mathrm{CO}_{\mathrm{x}}$ to methane can be catalyzed by several metals [12-14]. Some experimental works and density functional theory (DFT) calculations also indicate that ruthenium exhibits excellent activity in CO methanation $[1,4,15,16]$. Ruthenium dispersed on high-surface area oxide supports has been found to exhibit high activity in the methanation of $\mathrm{CO}$ and $\mathrm{CO}_{2}[3,5,13,14]$. Many literature reports give information about the influence of different factors on the activity of oxide-supported Ru systems $[1,6,7,12,13,16$, 17]. However, there are few papers dealing with the activity of ruthenium deposited on thermally modified carbons $[18,19]$. There is also lack of information concerning the effect of Ru crystallite sizes on the activity of $\mathrm{Ru} / \mathrm{C}$ systems. In the present work we made an effort to examine the influence of the ruthenium particle size in the wide range of its dispersion on the catalytic activity of Ru/graphitized carbon systems in $\mathrm{CO}$ methanation. The activity tests were conducted in $\mathrm{H}_{2}$-rich streams with very low $\mathrm{CO}$ concentrations $(0.5 \mathrm{vol} \% \mathrm{CO})$ to simulate industrial conditions of hydrogen cleaning for $\mathrm{NH}_{3}$ synthesis or fuel cells application. 


\section{Experimental}

\subsection{Catalyst Preparation}

Four graphitized carbon materials were used as supports for ruthenium. The supports were obtained from the commercially available activated carbon RO 08 (Norit Nederland B. V.) via high-temperature treatment of entire cylindrical extrudes $(6 \mathrm{~mm}$ long, id $0.8 \mathrm{~mm})$ of carbon $(2 \mathrm{~h}$, helium atmosphere) at temperatures: 1600, 1700, 1900 or $2300^{\circ} \mathrm{C}$. Finally, the materials were washed with distilled water and dried in air at $120^{\circ} \mathrm{C}$. The nitrogen physisorption studies were performed to determine the surface areas of the prepared carbon materials. Surface area measurements were carried out on the entire cylindrical extrudes of carbon using a ASAP 2020 apparatus (Micromeritics) with $\mathrm{N}_{2}$ at $-196^{\circ} \mathrm{C}$ as the sorbate. Specific surface areas were determined by the 5-point BET (Brunauer-Emmett-Teller) method. The obtained BET values with estimation errors are listed in Table 1. The carbon supports are marked throughout the text with symbols indicating their $\mathrm{S}_{\mathrm{BET}}$ values.

As one can see (Table 1), treatment of the carbon at higher temperatures led to a drastic decrease of the specific surface area $\left(\mathrm{S}_{\mathrm{BET}}\right)$. This is due to the graphitization of carbon and to the disappearance of micropores as evidenced by Kowalczyk et al. [20].

In order to prepare the Ru/carbon systems, the extrudes of carbon supports were impregnated with an acetone-water solution of ruthenium chloride $\left(\mathrm{RuCl}_{3} \cdot 0.5\right.$ $\mathrm{H}_{2} \mathrm{O}$ ). After drying in air at $90^{\circ} \mathrm{C}$, the samples were reduced in flowing hydrogen of high purity $(99.9999 \%)$ at atmospheric pressure-first at $150^{\circ} \mathrm{C}$ for $24 \mathrm{~h}$ and then at $370^{\circ} \mathrm{C}$ for $24 \mathrm{~h}$. Next, the material was cooled in argon and passivated with small air pulses added to an Ar stream at room temperature. The temperature increase in the sample was monitored during the passivation until no changes were observed. The nominal metal contents in the samples were calculated on the basis of the mass balance of the sample before impregnation and after reduction with the use of the mass of ruthenium chloride used in the impregnation [18]. The ruthenium content in the $\mathrm{Ru} /$ carbon systems was kept constant- the respective values are included in Table 1.
2.2 Estimation of the Ruthenium Particle Size in Ru/C Systems

The average size of ruthenium particles in all the catalysts was estimated with the use of the conventional chemisorption technique (volumetric experiments) using carbon monoxide as the adsorbate. The measurements were performed in a fully automated ASAP 2020 instrument (Micromeritics) at $35^{\circ} \mathrm{C}$. Prior to measurements, the sample $(0.15 \mathrm{~g}$, fraction $0.2-0.63 \mathrm{~mm}$ ) was reduced in flowing hydrogen $\left(80 \mathrm{~cm}^{3} / \mathrm{min}\right)$ of high purity $(>99.9999 \%)$ at $430^{\circ} \mathrm{C}$ for $10 \mathrm{~h}$. The chemisorption data were used for calculating the ruthenium dispersions and average sizes $\left(\mathrm{d}_{\mathrm{CO}}\right)$ of the metal particles. The $\mathrm{CO}: \mathrm{Ru}_{\mathrm{s}}=0.6: 1$ [18] stoichiometry and formula proposed by Borodziński and Bonarowska [21] were applied for calculating $\mathrm{d}_{\mathrm{CO}}$ values.

Ex-situ X-ray powder diffraction (XRPD) patterns were measured on the powdered samples using hybrid RigakuDenki X-ray diffractometer in Bragg-Brentano configuration (Ni filtered $\mathrm{Cu}$-sealed tube operated at $40 \mathrm{kV}$, $40 \mathrm{~mA}$ and stability of $0.01 \% / 8 \mathrm{~h}$ ) in the $2 \Theta$ angle range of $20^{\circ}-90^{\circ}$ (step $0.02^{\circ}$, counting rate $10 \mathrm{~s} / \mathrm{step}$ ) along with a scintillation counter. All XRPD patterns were analyzed using FITYK software [22]. Profiles of Ru (102) and (110) peaks were fitted with a model Pearson VII functions corresponding to hexagonal ruthenium phase $\mathrm{P} 63 / \mathrm{mmc}$. Average size of ruthenium crystallites was estimated using Scherrer's equation.

TEM images were recorded with a Philips CM20 Super Twin microscope, which provides a $0.25 \mathrm{~nm}$ resolution at $200 \mathrm{kV}$. The samples for TEM studies were prepared by grinding the materials in a mortar followed by their dispersion in methanol. A droplet of the suspension was finally placed on a microscope grid covered with a perforated carbon film.

\subsection{Catalytic Activity Studies}

Characterization experiments were accompanied by activity studies in $\mathrm{CO}$ hydrogenation. The catalytic tests of carbon monoxide methanation were carried out in a fixedbed continuous-flow tubular reactor (quartz tube with inner diameter of $10 \mathrm{~mm}$ ) at atmospheric pressure. The
Table 1 Characteristics of the carbon-supported ruthenium catalysts

\begin{tabular}{lllll}
\hline Catalyst symbol & $\begin{array}{l}\text { Symbol of car- } \\
\text { bon support }\end{array}$ & $\begin{array}{l}\text { Temperature of carbon } \\
\text { treatment in He }\left({ }^{\circ} \mathrm{C}\right)\end{array}$ & $\begin{array}{l}\mathrm{S}_{\mathrm{BET}} \text { of the carbon } \\
\text { support }\left(\mathrm{m}^{2} / \mathrm{g}\right)\end{array}$ & $\begin{array}{l}\text { Ru content in } \\
\text { the catalyst } \\
(\mathrm{wt} \%)\end{array}$ \\
\hline $\mathrm{Ru} / \mathrm{C}-171$ & $\mathrm{C}-171$ & 1600 & $171.0 \pm 2$ & 10.04 \\
$\mathrm{Ru} / \mathrm{C}-104$ & $\mathrm{C}-104$ & 1700 & $104.0 \pm 1.5$ & 10.00 \\
$\mathrm{Ru} / \mathrm{C}-66$ & $\mathrm{C}-66$ & 1900 & $66.0 \pm 1$ & 10.10 \\
$\mathrm{Ru} / \mathrm{C}-32$ & $\mathrm{C}-32$ & 2300 & $32.0 \pm 0.5$ & 10.13 \\
\hline
\end{tabular}


catalytic measurements were performed under steadystate conditions of temperature $\left(220-270^{\circ} \mathrm{C}\right)$ and $\mathrm{CO}$ content in the stream. $20 \mathrm{mg}$ of the catalyst sample (fraction $0.2-0.63 \mathrm{~mm}$ ) was placed in the reactor and then reduced in flowing hydrogen (purity: $99.999 \%, 40 \mathrm{Ncm}^{3} / \mathrm{min}$ ) at $400^{\circ} \mathrm{C}$ for $17 \mathrm{~h}$, followed by cooling in hydrogen to $270^{\circ} \mathrm{C}$. Then, $\mathrm{CO}$ (purity: $99.997 \%$ ) was added to the $\mathrm{H}_{2}$ stream ( $0.5 \mathrm{vol} \% \mathrm{CO} / 99.5$ vol\% $\mathrm{H}_{2}$, summary flow $80 \mathrm{Ncm}^{3} / \mathrm{min}$ ). The temperature conditions were maintained for $40 \mathrm{~min}$ and then the gas leaving the reactor was analyzed. After the analysis, the temperature in the reactor was lowered to next point and after stabilization the GC analysis was performed. The same procedure was repeated for each temperature point during the tests: $270-240-220^{\circ} \mathrm{C}$. The flow rate of the inlet gas stream was controlled by a mass-flow controller. The concentrations of carbon monoxide and methane in the outlet gas were monitored chromatographically, using a Trace 1310 instrument (Thermo Scientific) equipped with a flame ionization detector (FID) and a $\mathrm{CO}_{\mathrm{x}}$ methanizer. The inlet-outlet mass balance of $\mathrm{CO}$ served to calculate the $\mathrm{CO}$ conversion to methane and the average reaction rate. Finally, the activity of the $\mathrm{Ru} / \mathrm{C}$ catalysts were expressed as turnover frequencies (TOF, $\mathrm{s}^{-1}$ ) calculated on the basis of the ruthenium dispersion determined in chemisorption experiments.

\section{Results and Discussion}

\subsection{Catalyst Characterization}

The main goal of the research was to prepare the catalysts of different ruthenium particle sizes. Therefore, the average sizes of ruthenium particles in the Ru/carbon systems were estimated with the use of three different techniques. The data obtained by XRPD studies for all four $\mathrm{Ru} / \mathrm{C}$ catalysts were presented in Fig. 1. The same masses of $\mathrm{Ru} / \mathrm{C}$ samples (of constant $\mathrm{Ru}$ loading) were used for data collecting. For comparison, the diffraction pattern of one of the carbon supports (C-104) was also shown (Fig. 1a).

The reflections originating from the support material are characteristic for so called "turbostratic" carbon, containing graphite-like structures $\left(2 \Theta=26^{\circ}, 43^{\circ}, 55^{\circ}, 78^{\circ}\right.$ and $84^{\circ}$, Fig. 1a). As one can see, the only phases observed in XRPD patterns for $\mathrm{Ru} / \mathrm{C}$ samples were carbon and metallic ruthenium (Fig. 1 b,c). For all four catalysts sharp signal of graphite structures in the supports are clearly visible. $\mathrm{Ru}$ signals were also observed. The intensity of Ru reflections increases with lowering the surface area of the carbon. It is especially well visible at $2 \Theta=38^{\circ}, 44^{\circ}, 58^{\circ}$ and $69^{\circ}$ angles. Since the ruthenium content is generally the same in all cases, the observed trend should be ascribed to the increase of the average size of ruthenium crystallites, or more
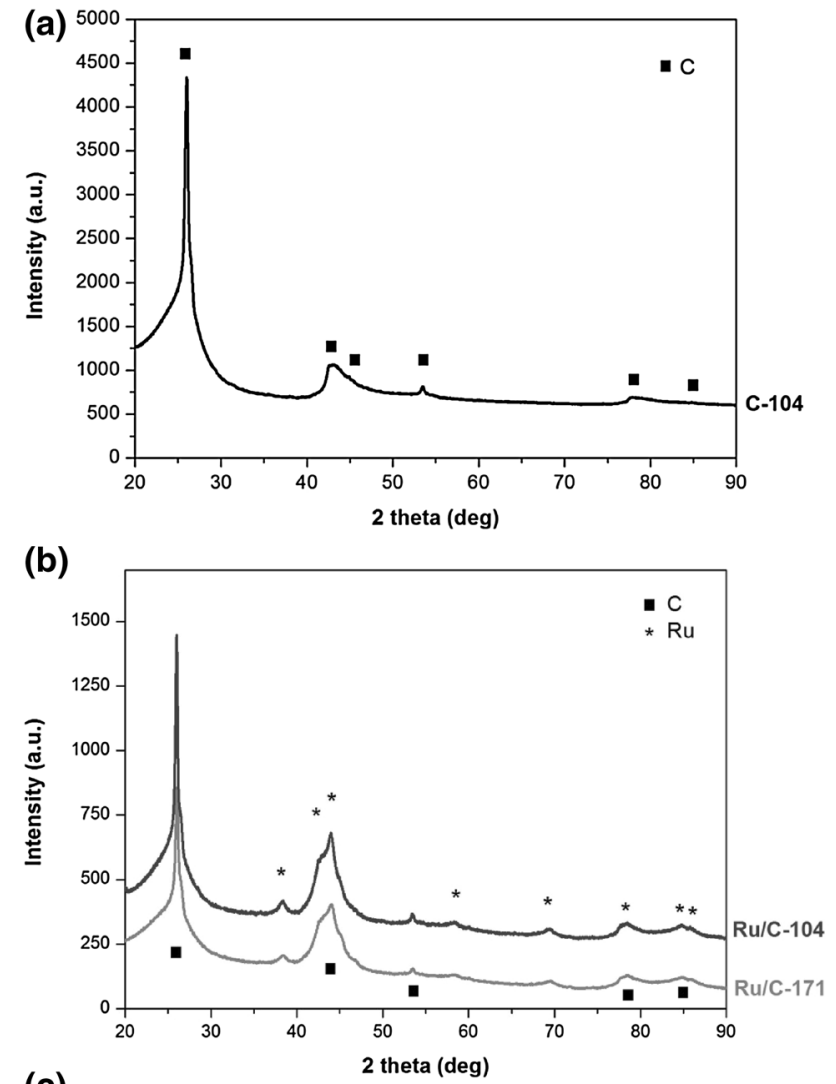

(c)

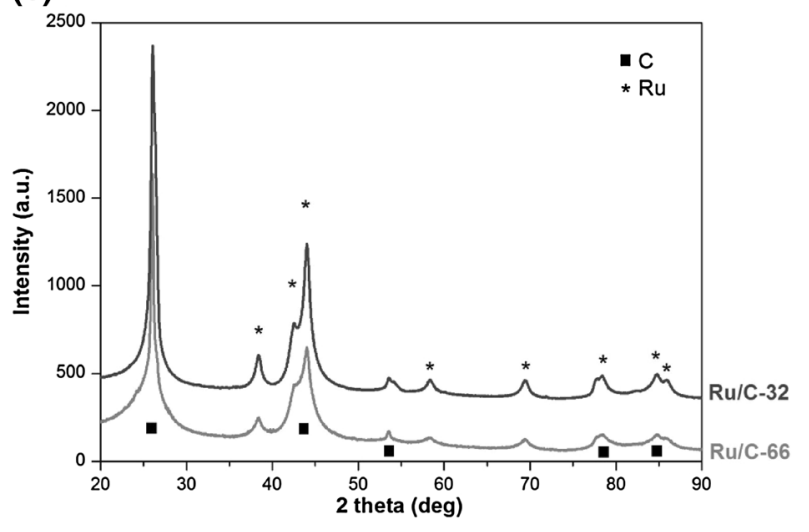

Fig. 1 XRPD patterns: a A selected carbon support C-104, b Ru catalysts supported on C-171 and C-104, $\mathbf{c}$ Ru catalysts supported on C-66 and C-32

directly - crystalline domains of ordered structure. The last one is a consequence of the support surface area, which determines ruthenium dispersion, as reported earlier for $\mathrm{Ru} /$ carbon catalysts dedicated for $\mathrm{NH}_{3}$ synthesis [23]. Several methods can be applied to determine the domain size of nanoparticles [24, 25]. However, they are often sensitive for the background subtraction which is difficult in complex, supported systems. That can lead to overestimation of metal crystallite sizes, especially in the case of broad particle size distribution, where the "diffraction response" from 
a fraction of very small crystallites can be hidden in the background. In such cases the use of the Scherrer formula is commonly accepted in the literature $[14,26]$. Therefore it was used to estimate the average sizes of ruthenium particles in the $\mathrm{Ru} /$ carbon systems. The obtained $\mathrm{d}_{\mathrm{XRPD}}$ values are collected in Table 2.

The estimated $d_{\text {XRPD }}$ values correspond well with the trend of the intensity of Ru reflections in the patterns presented in Fig. 1b,c. Although the error in estimation was about $0.5 \mathrm{~nm}$, the increasing trend of $\mathrm{d}_{\mathrm{XRPD}}$ was obtained: from $4 \pm 0.5$ to $8.5 \pm 0.5 \mathrm{~nm}$ when decreasing the carbon support BET area.

The chemisorption studies were also performed to estimate the $\mathrm{Ru}$ particle sizes. The classical volumetric experiments of $\mathrm{CO}$ adsorption allowed us to determine the amount of $\mathrm{CO}$ adsorbed on the reduced ruthenium surface. On that basis the average sizes of Ru particles were calculated. The chemisorption technique is commonly applied for the characterization of dispersion of supported metals $[7,13,27]$. The adsorbate covers the outer surface of all metal crystallites in the sample. Therefore, the estimated average size of metal particles takes into account the whole range of particle sizes and gives the information representative for the whole sample used. The results of chemisorption studies-"CO uptake" and $\mathrm{d}_{\mathrm{CO}}$ are presented in Table 2. The obtained values were determined to two decimal places. The consumption of $\mathrm{CO}$ per gram of the $\mathrm{Ru} / \mathrm{C}$ catalyst decreased by a factor of 2 when the carbon surface area decreased from 171 to $32 \mathrm{~m}^{2} / \mathrm{g}$. The $\mathrm{d}_{\mathrm{CO}}$ parameters were calculated with very low error of estimation-max $1 \%$. The average ruthenium crystallite size in $\mathrm{Ru} / \mathrm{C}$ systems increased with a decrease in the surface area of the carbon support: from $3.68 \pm 0.04 \mathrm{~nm}(\mathrm{Ru} / \mathrm{C}-171)$ to $8.53 \pm 0.04 \mathrm{~nm}$ for $\mathrm{Ru} / \mathrm{C}-32$. The $\mathrm{d}_{\mathrm{CO}}$ values obtained for $\mathrm{Ru} / \mathrm{C}-171$ and $\mathrm{Ru} / \mathrm{C}-104$ catalysts are slightly lower than $\mathrm{d}_{\mathrm{XRPD}}$ estimated on the basis of XRPD results. However, the general trend remains the same. It should be noticed that very small ruthenium particles (below ca. $2-4 \mathrm{~nm}$ in diameter) could be in the form not detectable via the conventional XRPD

Table 2 Characteristics of the $\mathrm{Ru} / \mathrm{C}$ catalysts - average Ru crystallites sizes (d) estimated by: $d_{C O}$ CO chemisorption, $d_{X R P D}$ XRPD and $d_{T E M}$ TEM

\begin{tabular}{lllll}
\hline Catalyst symbol & XRPD & \multicolumn{2}{l}{ Chemisorption results } & TEM \\
\cline { 3 - 4 } & $\mathrm{d}_{\text {XRPD }}(\mathrm{nm})$ & $\begin{array}{l}\text { CO uptake } \\
\left(\mathrm{cm}^{3} / \mathrm{g}\right.\end{array}$ & $\mathrm{d}_{\mathrm{CO}}(\mathrm{nm})$ & $\mathrm{d}_{\text {TEM }}(\mathrm{nm})$ \\
& & $\mathrm{STP})$ & & \\
\hline $\mathrm{Ru} / \mathrm{C}-171$ & $4.0 \pm 0.5$ & $4.20 \pm 0.05$ & $3.68 \pm 0.04$ & $2.5 \pm 1.0$ \\
$\mathrm{Ru} / \mathrm{C}-104$ & $5.5 \pm 0.5$ & $3.82 \pm 0.02$ & $4.13 \pm 0.02$ & $3.5 \pm 2.5$ \\
$\mathrm{Ru} / \mathrm{C}-66$ & $6.5 \pm 0.5$ & $2.63 \pm 0.02$ & $6.81 \pm 0.05$ & $4.5 \pm 2.0$ \\
$\mathrm{Ru} / \mathrm{C}-32$ & $8.5 \pm 0.5$ & $2.10 \pm 0.01$ & $8.53 \pm 0.04$ & $6.0 \pm 4.5$ \\
\hline
\end{tabular}

technique [16, 26, 28], giving contribution to the background, so the $\mathrm{d}_{\mathrm{XRPD}}$ values for $\mathrm{Ru} / \mathrm{C}-171$ and $\mathrm{Ru} / \mathrm{C}-104$ catalysts could be slightly over-estimated. Therefore, it should be emphasized that ruthenium crystallite sizes estimated by chemisorption and XRPD stay in a very good agreement.

Transmission electron microscopy was used to observe the structure of carbon materials and the prepared catalysts. Figure 2 presents the selected, representative images of C-171, C-66 and C-32 carbon supports obtained by treatment in helium at 1600,1900 or $2300^{\circ} \mathrm{C}$, respectively (see Table 1).

It is clearly visible that a higher temperature of the additional treatment led to the increase of the amount and thickness of ordered structures in the carbon matrix. Distances between the lattices observed by TEM are close to that characteristic for graphite: $0.34 \mathrm{~nm}$. For C-32 thick slabs of highly graphitized carbon appear. The representative TEM images for $\mathrm{Ru} / \mathrm{C}$ systems are presented in Fig. 3 .

As one can see (Fig. 3), the ruthenium particles in four $\mathrm{Ru} / \mathrm{C}$ catalysts examined are round-shaped regardless of the carbon support used. It is worth noting that the particles are more homogeneous in size when the surface area of the carbon material is better developed (Fig. 3). The particles size distribution plots were made for each catalyst (plots not presented). On that basis the average Ru particle sizes $\left(\mathrm{d}_{\text {TEM }}\right)$ were estimated. They are presented in Table 2 with estimation error values. It was observed that the average sizes of Ru crystallites increased with lowering surface area of the support. The $\mathrm{d}_{\mathrm{TEM}}$ values increased from $2.5 \pm 1 \mathrm{~nm}$ for $\mathrm{Ru} / \mathrm{C}-171$ sample to $6.0 \pm 4.5 \mathrm{~nm}$ for $\mathrm{Ru} / \mathrm{C}-32$. The particle size distribution plots became wider with decreasing carbon support area, in accordance with literature reports [26]. In consequence, the errors of the average $\mathrm{d}_{\text {TEM }}$ estimation increased significantly. The average $d$ values obtained on the basis of TEM images are slightly lower when compared to $d_{\text {CO }}$ or $d_{\text {XRPD }}$ (Table 2). It is commonly known that the analysis of TEM data is restricted to the number of images recorded for a small part of the sample lighted by the electron beam [25]. In consequence, the average particle sizes obtained through analysis of TEM images could be not representative for the whole catalyst sample, especially in the case of heterogeneous materials. In spite of these limitations, the general trend of $d$ values was the same regardless of the technique used (Table 2).

\subsection{CO Hydrogenation}

Finally, the $\mathrm{CO}$ methanation tests were conducted to determine the effect of the active phase crystallite sizes on the activity of $\mathrm{Ru} /$ carbon systems. The main product of $\mathrm{CO}$ hydrogenation over $\mathrm{Ru} / \mathrm{C}$ catalysts was $\mathrm{CH}_{4}$. Only trace amounts of higher $\mathrm{C}_{x} \mathrm{H}_{y}$ were detected. The activity of the 

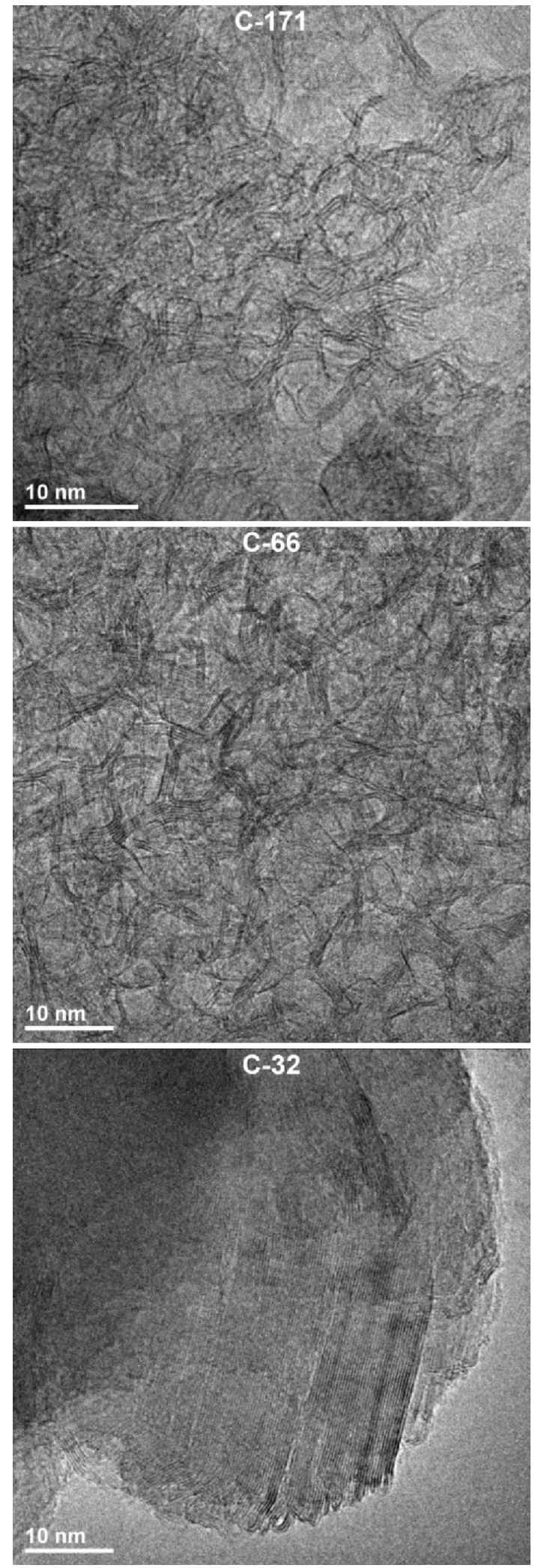

Fig. 2 TEM images of C-171, C-66 and C-32 carbon supports catalysts was expressed in terms of turn-over frequencies (TOF). The TOF values were determined by combining the reaction rates and $\mathrm{CO}$ chemisorption results. The data obtained during the tests at 240 and $220^{\circ} \mathrm{C}$ are presented in Table 3.

As shown in Table 3, the activity of Ru/carbon catalysts changes with the increase of average ruthenium particle size (compare Table 2) at both temperatures. The maximum activity for the methanation (TOF) was reached for $\mathrm{Ru} / \mathrm{C}-66$ catalyst having ruthenium crystallites of ca $6.8 \mathrm{~nm}$ in diameter, independent on the temperature. Samples that contained smaller ( $\mathrm{Ru} / \mathrm{C}-104)$ or larger (Ru/C-32) ruthenium particles (average "d" values, Table 2) exhibited lower surface-based activities (TOF). The lowest activity level was obtained for Ru/C-171 catalyst (Table 3). The obtained particle size dependency implies the structure sensitivity of CO methanation over ruthenium.

Literature reports concerning the dependence of the activity of Ru-based systems in $\mathrm{CO}$ methanation on the $\mathrm{Ru}$ particle size are ambiguous. According to Zhang et al. [1] highly dispersed $\mathrm{Ru}$ particles in $\mathrm{Ru} / \mathrm{Al}_{2} \mathrm{O}_{3}$ systems are more active than large particles. However, the authors [1] did not indicate the exact particle diameter. For $\mathrm{Ru} / \mathrm{TiO}_{2}$ systems Tada et al. [28] and Wang et al. [16] concluded that smaller $\mathrm{Ru}$ particles promote $\mathrm{CO}$ methanation due to an increase in $\mathrm{CO}$ methanation active sites. Moreover, Wang et al. [16] supposed that the observed difference in the activity should be ascribed to the interaction between $\mathrm{Ru}$ nanoparticles with $\mathrm{TiO}_{2}$ supports rather than to different $\mathrm{Ru}$ particle size. On the other hand, there are many papers suggesting the opposite trend. Okuhara et al. [27] reported an increase of TOF of CO methanation as the dispersion of $\mathrm{Ru}$ decreased in $\mathrm{Ru} / \mathrm{Al}_{2} \mathrm{O}_{3}$ systems. Eckle et al. [29] discovered that increasing the $\mathrm{Ru}$ mean particle size from 0.9 to $1.9 \mathrm{~nm}$ causes an increase of activity for $\mathrm{CO}$ methanation over Ru/zeolite catalysts. Extended studies performed by Panagiotopoulou et al. [13] demonstrated that TOF of $\mathrm{CO} / \mathrm{CO}_{2}$ hydrogenation over $\mathrm{Ru}$ catalysts depends on the metal crystallite size. TOF values for $\mathrm{Ru} / \mathrm{TiO}_{2}$ presented in [13] increased by a factor of 40 with increasing mean crystallite size of $\mathrm{Ru}$ from 2.1 to $4.5 \mathrm{~nm}$. Similar results were published by Abe et al. [30], who reported that the catalytic activity of $\mathrm{Ru} / \mathrm{TiO}_{2}$ in $\mathrm{CH}_{4}$ formation increased when increasing the $\mathrm{Ru}$ particle size from 2.5 to $6 \mathrm{~nm}$ and next remained almost constant for particle diameters greater than about $6 \mathrm{~nm}$. Masini et al. [31] found that the TOF of $\mathrm{CO}$ methanation for $\mathrm{Ru} / \mathrm{SiO}_{2}$ catalysts with $\mathrm{Ru}$ nanoparticles with diameter of 4-10 $\mathrm{nm}$ increased slightly for higher particle size $(7-10 \mathrm{~nm})$. In the case of carbon-supported systems Kowalczyk et al. [32] reported that surface- based reaction rate (TOF) of $\mathrm{CO}$ methanation $(3000 \mathrm{ppm} \mathrm{CO}$ in the gas mixture) increased with increasing $\mathrm{Ru}$ particle size up to $6 \mathrm{~nm}$, however, no maximum was reached and the 
Fig. 3 TEM images of the Ru/ carbon catalysts
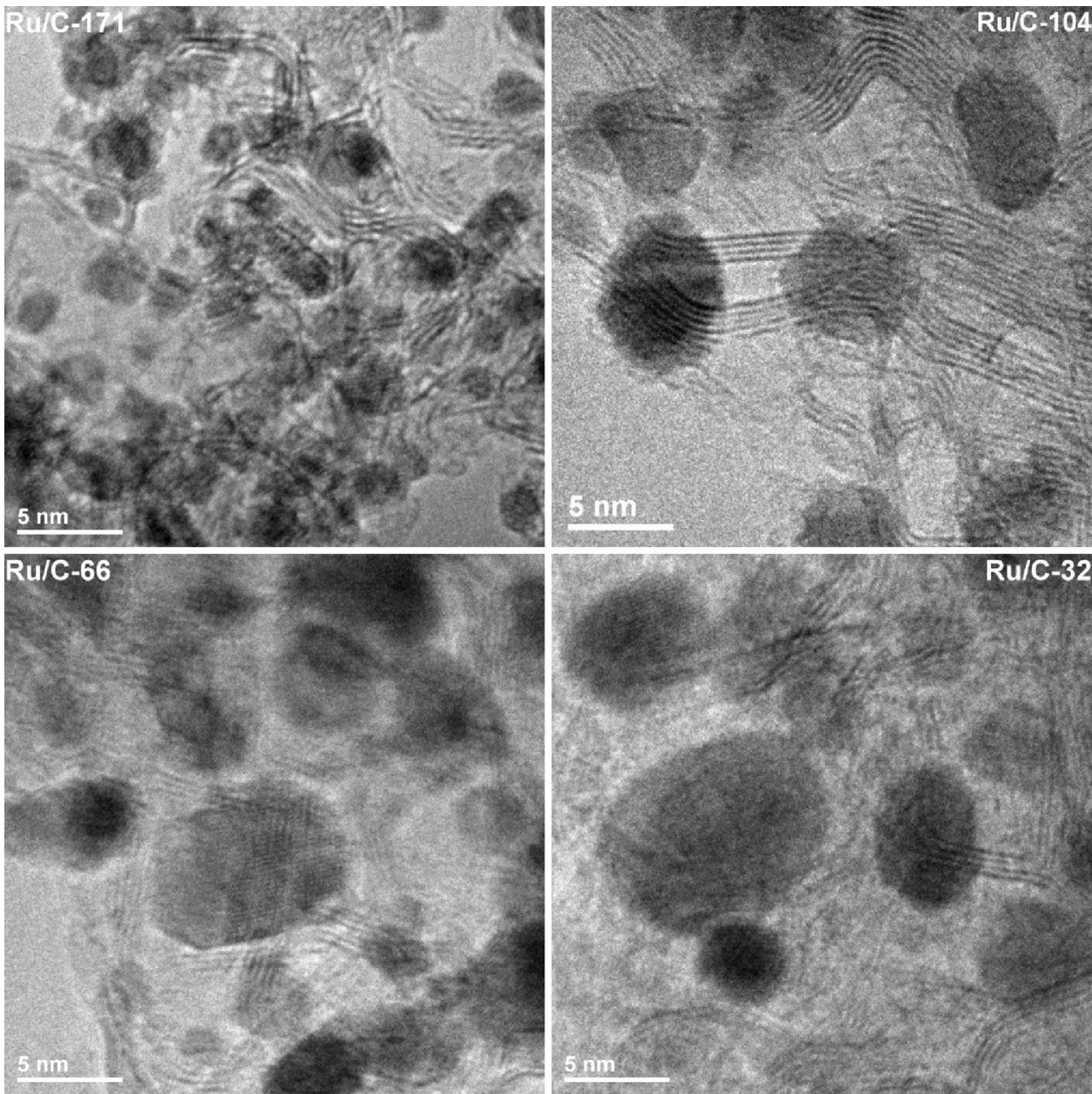

Table 3 Catalytic activity of the studied catalysts in $\mathrm{CO}$ methanation: surface-based activities (TOF) and metal weight-based reaction rates $(\mathrm{r})$ at $1 \mathrm{~atm}$, in $0.5 \mathrm{vol} \% \mathrm{CO} / \mathrm{H}_{2}$

\begin{tabular}{llllll}
\hline Catalyst symbol & \multicolumn{2}{l}{$220^{\circ} \mathrm{C}$} & & \multicolumn{2}{l}{$240^{\circ} \mathrm{C}$} \\
& $\mathrm{TOF} \times 10^{3}(1 / \mathrm{s})$ & $\mathrm{r}\left(\mathrm{mmol}_{\mathrm{CH} 4} / \mathrm{g}_{\mathrm{M}} \mathrm{h}\right)$ & & $\mathrm{TOF} \times 10^{3}(1 / \mathrm{s})$ & $\mathrm{r}\left(\mathrm{mmol}_{\mathrm{CH} 4} / \mathrm{g}_{\mathrm{M}} \mathrm{h}\right)$ \\
\hline $\mathrm{Ru} / \mathrm{C}-171$ & $6.5 \pm 0.1$ & $74.0 \pm 0.9$ & & $15.6 \pm 0.2$ & $178.0 \pm 2.7$ \\
$\mathrm{Ru} / \mathrm{C}-104$ & $12.2 \pm 0.4$ & $127.0 \pm 3.7$ & & $29.6 \pm 0.9$ & $306.0 \pm 9.5$ \\
$\mathrm{Ru} / \mathrm{C}-66$ & $19.1 \pm 0.4$ & $136.0 \pm 3.1$ & & $44.0 \pm 1.9$ & $314.0 \pm 13.5$ \\
$\mathrm{Ru} / \mathrm{C}-32$ & $13.46 \pm 0.1$ & $76.1 \pm 0.5$ & & $31.2 \pm 0.1$ & $177.6 \pm 0.4$ \\
$\mathrm{RANG}-19 *$ & - & $125.5 \pm 0.9$ & & - & $287.5 \pm 0.9$ \\
\hline
\end{tabular}

*The Ni-based industrial catalyst manufactured by the New Chemical Syntheses Institute in Puławy (Poland) optimal $\mathrm{d}_{\mathrm{Ru}}$ value was not indicated. Therefore, our results seem to extend the previous findings to the larger Ru crystallite sizes.

The last paragraph will be devoted to the comparison between the ruthenium/carbon systems and industrial nickel catalyst (RANG-19: 16.1 wt. $\% \mathrm{Ni} / \mathrm{Al}_{2} \mathrm{O}_{3}$, manufactured by the New Chemical Syntheses Institute in Puławy, Poland) for $\mathrm{CO}_{\mathrm{x}}$ hydrogenation. From the practical point of view, the reaction rates referred to the catalyst volume are of the greatest importance [32]. However, ruthenium is an expensive metal and the activity referred to the metal mass seems to be important too. The activity of the catalysts expressed in terms of average metalweight based reaction rates are collected in Table 3. As seen in Table 3, the weight-based reaction rates obtained for two ruthenium catalysts $(\mathrm{Ru} / \mathrm{C}-104$ and $\mathrm{Ru} / \mathrm{C}-66)$ at both temperatures $\left(240\right.$ and $\left.220^{\circ} \mathrm{C}\right)$ and $0.5 \mathrm{vol} \% \mathrm{CO}$ in the inlet gas are higher than that for the nickel catalyst (RANG-19). The above comparison suggests that 
ruthenium/carbon catalysts may be potentially applied in the industrial $\mathrm{CO}$ methanation in the future.

\section{Conclusions}

The average particle size of Ru in carbon-supported catalysts depends on the carbon texture: the higher $\mathrm{S}_{\mathrm{BET}}$ of the carbon support, the higher the dispersion of Ru. The change of the $\mathrm{d}_{\mathrm{Ru}}$ value in $\mathrm{Ru} /$ carbon catalysts causes a significant difference in their catalytic activity in $\mathrm{CO}$ methanation. In the studied range of sizes of ruthenium particles supported on carbon the highest methanation activity expressed in terms of TOF was achieved for ruthenium crystallites of ca. $6.8 \mathrm{~nm}$ in diameter. It can be supposed that $\mathrm{CO}$ methanation over ruthenium catalyst based on graphitized carbon is "structure sensitive". There may be an optimal size of Ru crystallites, which provides the highest level of activity. Further work is necessary to confirm this.

Acknowledgements This work was financed from the National Science Centre funds; Decision Number DEC-2011/01/D/ST8/07157.

Open Access This article is distributed under the terms of the Creative Commons Attribution 4.0 International License (http:// creativecommons.org/licenses/by/4.0/), which permits unrestricted use, distribution, and reproduction in any medium, provided you give appropriate credit to the original author(s) and the source, provide a link to the Creative Commons license, and indicate if changes were made.

\section{References}

1. Zhang Y, Zhang G, Wang L, Xu Y, Sun Y (2012) J Ind Eng Chem 18:1590-1597

2. Sehested J, Larsen KE, Kustov AL, Frey AM, Johannessen T, Bligaard T, Andersson MP, Nørskov JK, Christensen CH (2007) Top Catal 45:9-13

3. Martinȩz Tejada LM, Muñoz A, Centenò MA, Odriozola JA (2016) J Raman Spectrosc 47:189-197

4. Panagiotopoulou P, Kondarides DI, Verykios XE (2012) Catal Today 181:138-147

5. Lang SM, Bernhardt TM, Krstić M, Bonačić-Koutecký V (2014) Angew Chem Int Ed 53:5467-5471

6. Xiong J, Dong X, Li L (2012) J Nat Gas Chem 21:445-451

7. Galletti C, Specchia S, Saracco G, Specchia V (2010) Chem Eng Sci 65:590-596
8. Liu Q, Tian Y, Ai H (2016) RSC Adv 6:20971-20978

9. Gao J, Wang Y, Ping Y, Hu D, Xu G, Gu F, Su F (2012) RSC Adv 2:2358-2368

10. Gao J, Liu Q, Gu F, Liu B, Zhong Z, Su F (2015) RSC Adv 5:22759-22776

11. Huo X, Wang Z, Huang J, Zhang R, Fang Y (2016) RSC Adv 6:24353-24360

12. Djinović P, Galletti C, Specchia S, Specchia V (2011) Catal Today 164:282-287

13. Panagiotopoulou P, Kondarides DI, Verykios XE (2009) Appl Catal B 88:470-478

14. Jiménez V, Sánchez P, Panagiotopoulou P, Valverde JL, Romero A (2010) Appl Catal A 390:35-44

15. Andersson MP, Bligaard T, Kustov A, Larsen KE, Greeley J, Johannessen T, Christensen CH, Nørskov JK (2006) J Catal 239:501-506

16. Wang G, Gao Y, Wang W, Huang W (2012) Chin J Chem Phys 25:475-480

17. Tada S, Kikuchi R, Urasaki K, Satokawa S (2011) Appl Catal A 404:149-154

18. Kowalczyk Z, Stołecki K, Raróg-Pilecka W, Miśkiewicz E, Wilczkowska E, Karpiński Z (2008) Appl Catal A 342:35-39

19. Truszkiewicz E, Raróg-Pilecka W, Zybert M, WasilewskaStefańska M, Topolska E, Michalska K (2014) Pol J Chem Technol 16:106-110

20. Kowalczyk Z, Sentek J, Jodzis S, Diduszko R, Presz A, Terzyk A, Kucharski Z, Suwalski J (1996) Carbon 34:403-409

21. Borodziński A, Bonarowska M (1997) Langmuir 13:5613-5620

22. Wojdyr M (2010) J Appl Cryst 43:1126-1128.

23. Truszkiewicz E, Raróg-Pilecka W, Schmidt-Szałowski K, Jodzis S, Wilczkowska E, Łomot D, Kaszkur Z, Karpiński Z, Kowalczyk Z (2009) J Catal 265:181-190

24. Langford JI, Louër D, Scardi P (2000) J Appl Cryst 33:964-974

25. Canton P, Fazzini PF, Meneghini C, Benedetti A, Pozzi G (2008) Nanoscale characterization of metal nanoclusters by means of $\mathrm{X}$-ray diffraction (XRD) and transmission electron microscopy (TEM) techniques. In: Schmid G, Toshima N, Corain B (eds) Metal nanoclusters in catalysis and materials science: the issue of size control, Elsevier, Amsterdam, pp 129-147

26. Raróg-Pilecka W, Miśkiewicz E, Szmigiel D, Kowalczyk Z (2005) J Catal 231:11-19

27. Okuhara T, Kimura T, Kobayashi K, Misono M, Yoneda Y (1984) Bull Chem Soc Jpn 57:938-943

28. Tada S, Kikuchi R (2014) Catal Sci Technol 4:26-29

29. Eckle S, Augustin M, Anfang H-G, Behm RJ (2012) Catal Today 181:40-51

30. Abe T, Tanizawa M, Watanabe K, Taguchi A (2009) Energy Environ Sci 2:315-321

31. Masini F, Strebel ChE, McCarthy DN, Nierhoff AUF, Kehres J, Fiordaliso EM, Nielsen JH, Chorkendorff I (2013) J Catal 308:282-290

32. Kowalczyk Z, Stołecki K, Raróg-Pilecka W, Miśkiewicz E, Wilczkowska E, Karpiński Z (2008) Pol J Chem 82:607-612 